日薬理誌 (Folia pharmacol. japon.) 69, 153 161 (1973)

\author{
動物群集心理学の薬理学への導入一 9 \\ El-マウス痤㝈の日内リズムと6:00 p.m.に \\ おける相互関係ならび抗症變薬 \\ 喜多富太郎, 秦 多惠子, 尾陰多津子 \\ (近畿大学 薬学部 菜理学教室) \\ (昭和47年 8 月 5 日受付〔特了)
}

\begin{abstract}
緒言

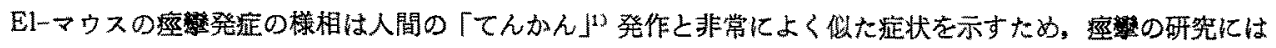

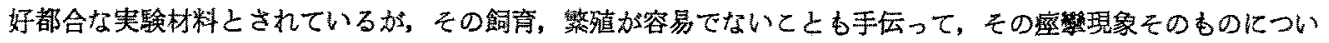

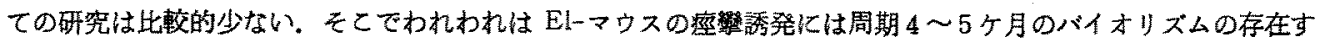

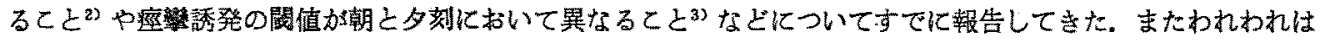

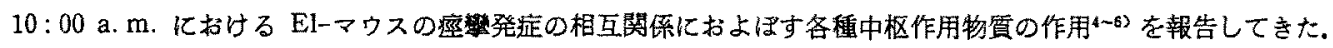

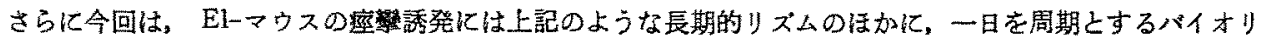

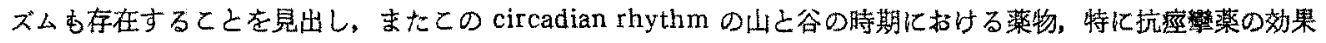
の異同についてる調べたので報告する.

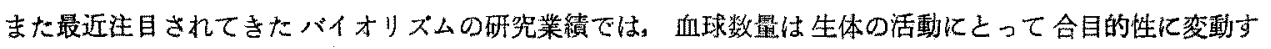

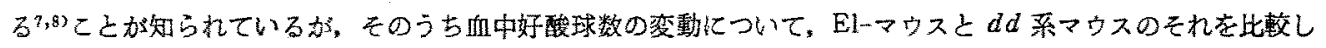
ながら長期にわたって調べたのでてれす併せて莭告する。.
\end{abstract}

\title{
実験材料ならびに実験方法
}

実験動物としては $d d$ 系マウス标よび E1ーマウスを使用した.E1ーマウスは前報までと同様 E1-F-30 系統の マウスを睢雄の別なく用いた。

使用薬物は phenobarbital, diphenylhydantoin, $\gamma$-aminobutyric acid (GABA), $\beta$-hydroxy $\gamma$-aminobutyric acid (GABOB), $\beta$-phenyl $\gamma$-aminobutyric acid (P-GABA) 标占び imidazol acetic acid-HCl (IA) ある.

これらの薬物のうち水溶性のものは $0.9 \% \mathrm{NaCl}$ に溶解し，水に不溶のものについては $2 \%$ アラ゙アゴム液

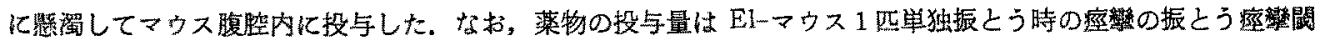
值 (TSC) や不発作率 (RNC) 亿影響老与え标い量とし，濃度はマウスへの投与量加 $0.1 \mathrm{ml} / 10 \mathrm{~g} \mathrm{~b} . \mathrm{w}$. とな

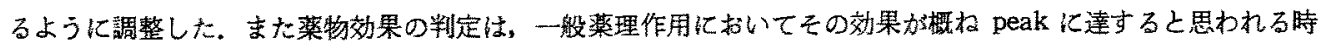
間に行なった。

好酸球数の算定はHinkelmann 法を応用して，マウスの尾より採った血液をHinkelmann 氏希积淮て 3 倍に希积し,Thoma 氏血球計算盤上で湿徽鏡下に数えた。希积液は本溶性黄色エオジン $0.5 \mathrm{~g}$ ，ホルマリン原 液 $0.5 \mathrm{ml}, 95 \%$ 石炭酸水溶液 $0.5 \mathrm{ml}$ 亿蒸留水を加えて $100 \mathrm{ml}$ としたものを用いた。

なお，採血操作そのものが マウスに対して一種の stressor となるととも考えられ，頻繁倸血するととれ が原因で好酸球の減少が見られるため同一マウスからの採血は一週に一回上した.

E1-マウスの振とう刺激は60回を限度とし，てれに達してす痤綎発作の見られないすのは不発作として取り 报った。 また痤繁発症の相互関係やその整理方法等についてはすへて前報4,65までの方法に準じて行なった。 


\section{I 连倸誘発のバイオリズムと年令}

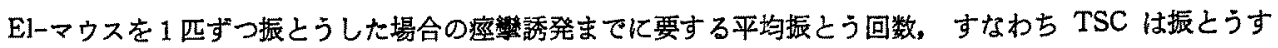

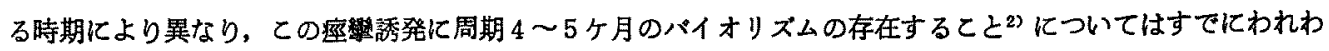
れが報告したとてろである。.その場合のリズムは種々の年令の混った多くのEl一マウスにおいて平均的に見られ たものであった. この4〜5ケ月周期のバイオリズムをさらに支持する実験として，出生期を一にする特定のグ ループについて1匹ずつ振とうした場合の TSC の変動を調へてみると Fig. 1 のようであった.

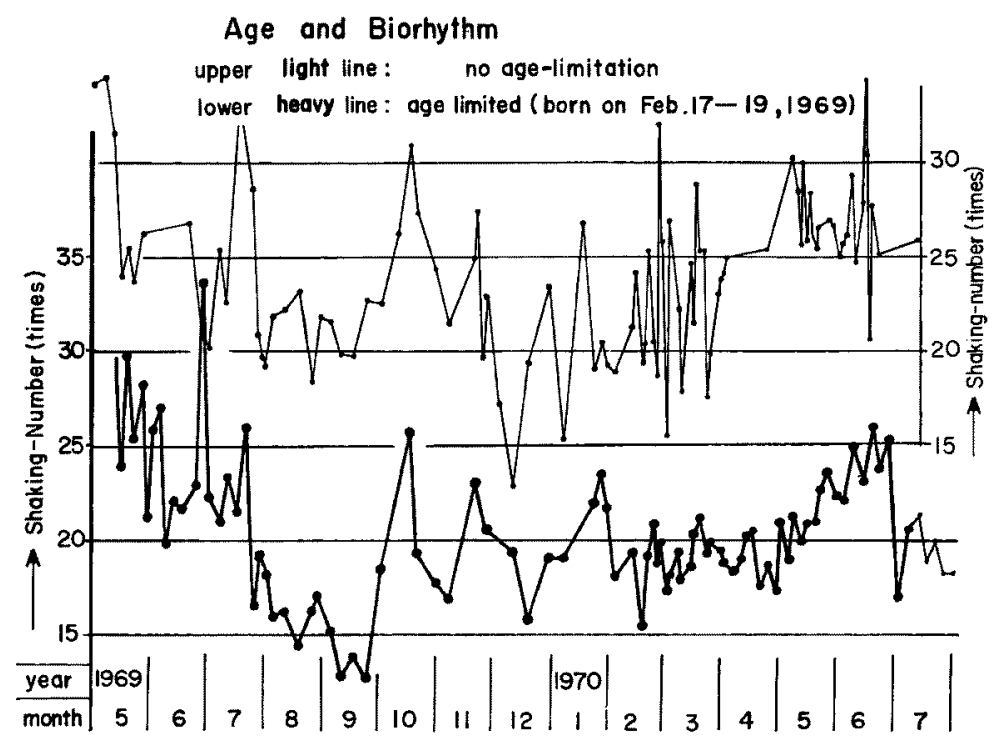

Fig. 1.

Fig. 1 では横軸に振とう実験を行なった年月日を, 縱軸に 1 匹振とう時の TSC を示している.

Fig. 1 の二つの折れ線グラフの内, 上方の細い線で示したグラフは年令に 関係なく出生期を巽にする多く の成熟マウス総群において見られる TSC のリズムであり，おのおの20〜50匹の平均值で示されている. 下方の 太い線で示したグラフは1969年 2 月17日〜19日という限られた 3 日間に出生した25匹のマウスについて1匹ずつ 振とうした場合の TSC である.

この二つのグラフを比較すると，TSC の大きさは翼なるがそのリズムは概ね同しである。

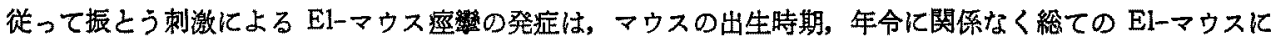
ついて一定のリズムをすっていることはほほ確実であると考えられる.

\section{El-マウス座算誘発の日内リスム}

Fig. 1 は El-マウス痙察についての長期にわたるパイオリズムであったが，このTSC は一日のうちではど うなっているのか. 朝と夕刻によって TSC にかなり大きな差異加あるというてどはすずて報告しているが， 今回はそのような 2 時点のみでなく，一日 $24^{\mathrm{h}}$ の間，2，6，10，14，18および22時という $4^{\mathrm{n}}$ 每に TSC を調へ てみた。 その結果を Fig. 2 亿示す.

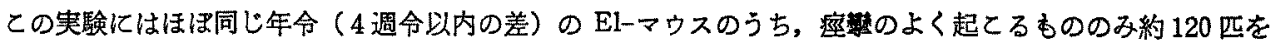
選んで使用した. マウスを 6 群に等分し，1群ずつ前記の各時刻に割当てて振とうした。一日の振とう実験は朝 6 時から始め翌朝10時まで続けられた。.Fig. 2 の值仕同じ実験を $2 \sim 4$ 日間隔で 4 回行なって得た值の平均値 である. 


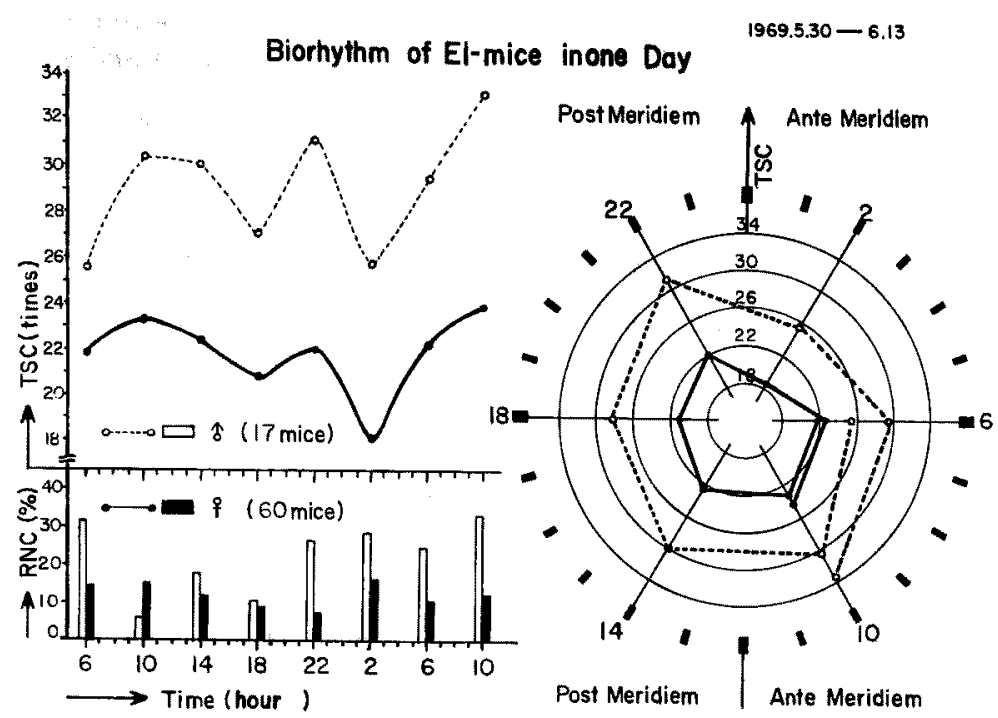

Fig. 2.

その祭マウス各群の特性か強調され実験值に影響を与えないように考慮し，各回の実験毎に各振とう時刻に 割当てるマウスのグループは同じにならないよう交替して振とうした.

Fig. 2 の左図は横軸に振とう時刻を示し，絴軸は上図ではTSC（回数）を，下図では RNC（\%) を示す. また上図の破線は雄性マウスの，実線は倠性マウスのTSC リズムであり，下図で 雌性マウスの RNC を示す。

因に見られるように午前 2 時の TSC が最あ小さくて病攀が非常に起てり易く, 次いで午後 6 時が TSC の 第二の谷となっている。 また午前10時之午後10時にはTSCリズムは山となっており，その前後の時刻䎲比でて

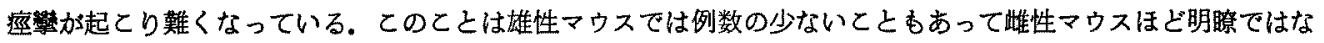
いが，両性マウス共に概㕲同じととがいえる.

下図の RNC の変化についてははっきりした傾向は認められない。

また Fig. 2 右側の図は，一日 $24^{\mathrm{h}}$ を円で示し，TSC を同心円上に示したものである. この図においては 2 時の值が最す内側の円上にあり TSC の小さいととが認められ，10時と22時の值加最も外側の円上にあり，と の円形グラフは10時と22時をつなぐ方向に引っ張られた形となっており，ての時刻を中心に氫慗が起とり難くな っているととが簣える.

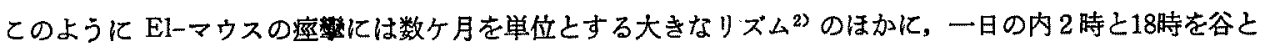
し，10時と22時を山とする日内リズムも存在するととが認められた.

\section{.III 血中好酸球数の変䵢}

血球数量は生体の活動にとって合目的性に変動するととはよく知られているが，その内好酸球については， ストレスと関係して大きく変動することは古く加ら知られているてとである. またヒトでは好酸球数に日内りス ムがある゙といわれている.

ての好酸球数をマウスについて長期にわたって調べた. その結果を Fig. 3 亿示す.

E1ーマウスならびに $d d$ 系マウスについてその好酸球数を 4 7 ケ月にわたって測定した. Fig. 3 の横軸は 測定開始以来の日数を, 維軸は血液 $1 \mathrm{~mm}^{3}$ 中の好酸球数 (個 $/ \mathrm{mm}^{3}$ ) を示す. 图の左は $d d$ 系マウスについて, 右は E1-マウスについてであり，いずれもほほ10匹の平均值で示している.

マウスの好酸球数については Fig. 3 に見るどとくバイオリズムの存在することが明らかである. 因中，折 


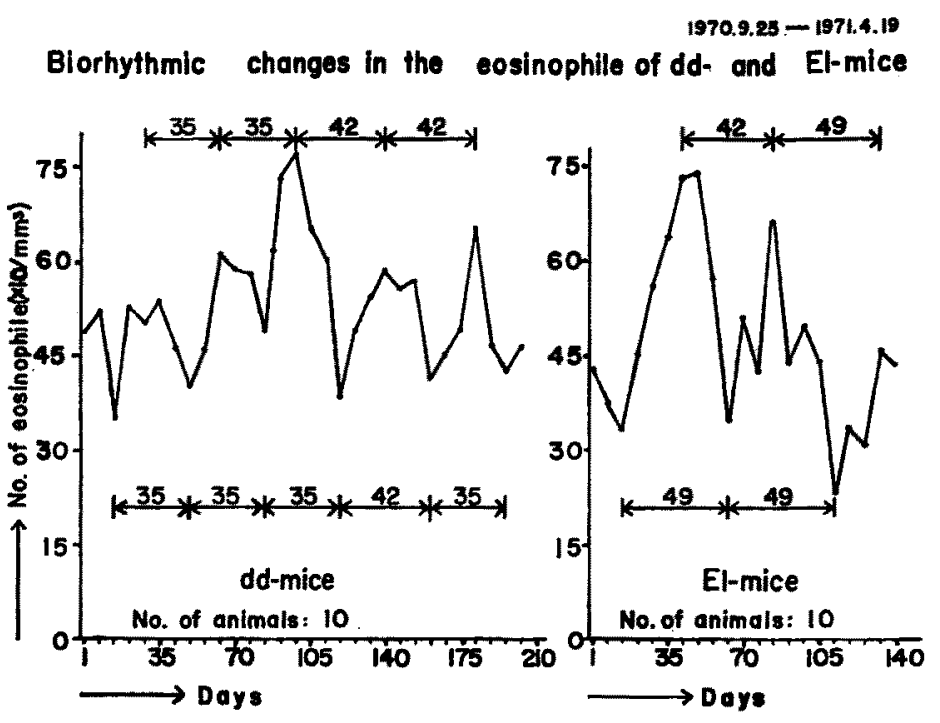

Fig. 3.

れ線グラフの上方または下方に矢印と共に記してある数字はそれぞれ好酸球数変動りズムの山から山ままたは谷 加谷までの日数を示している．てれらの数字，すなわちリズムの周期は $d d$ 系マウスでは35〜42日，Elーマウ スでは42〜49日である.

てれは 1 週間每に測定しているためその中間の值は出てこないが，とこに得られた数值から平均をとってみ ると $d d$ 系マウスでは約37日，El-マウスでば約47日という周期汃得られ，dd 系マウスに比へて E1-マウスの 方が周期加長くなっている.

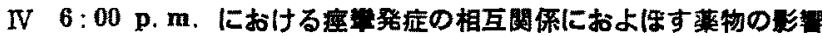

IIで示したどとく El一マウスの TSC に日内リズムの存在することが認められたが，このととから一日の内

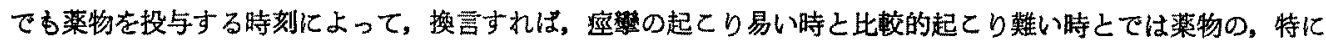
抗座賟の効果の異なることが考えられる.

そてで Fig. 2 に示されたリズムの内，TSC の大きい山である 10:00 a.m. と TSC の小さな谷である

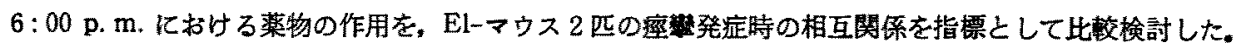

Table 1 には 10:00 a. m. に打りる相互関係に対する種々薬物の効果を示している. との表は前報山の゙まて 代報告した成績をまとめたすのであり，図中の矢印はそれそれれの相互関係が薬物により移動した方向とその大き さを示し，一は影響の見られない場合をまたさは一定の影響の見られない場合を意味する。

Table 1 の成績は $10: 00 \mathrm{a} . \mathrm{m}$. (以下朝と記す) という比較的痓䩙の起こり難い時刻での薬物の作用である.

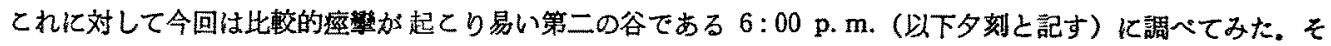
れらの成綪を Figs 4 9 亿示し, Table 1 の成績と此敘しながら述べる.

最初に同調率（Simultaneity，以下 Sim 之略）とRNC を指踒とした 2 匹間の相互関係に対する薬物の影 響を Figs 4〜6 に示した。

Phenobarbital $1.5 \mathrm{mg} / \mathrm{kg}$ を投与，90m 後の成䌙は，Table 1 の朝では左上に大きく移動し，2匹間の Sim の隇少，RNC の増加汃見られたのに対し，夕刻ではFig. 4 亿見るごとく，その相互関係はほとんど移動せず, phenobarbital の影辢仙認められたくなった。

Diphenylhydantoin $7.0 \mathrm{mg} / \mathrm{kg}$ を投与, $100 \mathrm{~m}$ 後の成績では, 朝と同様夕刻でも左上に大きく移動した. 次に朝の成績では以前の論文5)で相互関係の移動先は正常筙囲内の特定の領域に集まる傾向が見られ，中枢 
Table 1.

Influence of various materiais on mutual relation of 2 El-mice

\begin{tabular}{|c|c|c|c|}
\hline Mlaterials & ${ }_{\text {simultansily }}$ & & $\underset{\text { Propogotion }}{\mathrm{L}}$ \\
\hline $\begin{array}{l}\text { DL-amphetamine } \\
\text { coffeine } \\
\text { pentefrozol } \\
\text { pitrotoxin } \\
\text { itripromine } \\
\text { visccompher } \\
\text { nicethomide } \\
\text { dimorpholanine }\end{array}$ & $\underset{+}{\stackrel{-}{+}}$ & $\begin{array}{l} \pm \\
\pm \\
\pm\end{array}$ & $\begin{array}{l}\longrightarrow \\
\pm \\
\pm \\
- \\
- \\
-\end{array}$ \\
\hline $\begin{array}{l}\text { chlorpromazine } \\
\text { chlordiazepoxide } \\
\text { diphenhydramine }\end{array}$ & & & $\begin{array}{l}- \\
\pm\end{array}$ \\
\hline $\begin{array}{l}\text { phenobarbital } \\
\text { diphenylhydanioin } \\
\text { imidazole acetic acid }\end{array}$ & 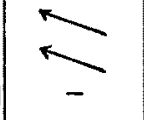 & & $\begin{array}{l} \pm \\
\pm \\
\pm\end{array}$ \\
\hline $\begin{array}{l}\text { GABA } \\
\text { GABOB } \\
\text { P-GABA }\end{array}$ & & $\vec{\uparrow}$ & $\leftarrow$ \\
\hline
\end{tabular}

$-:$ no influence \pm : indistinct

$1971.7 .5-7.28$

Rolationship between Simultanelty $\mathbf{a}$ RNC in $2 \mathrm{EI}-$ mice offer odministrotion of anticonvulsants
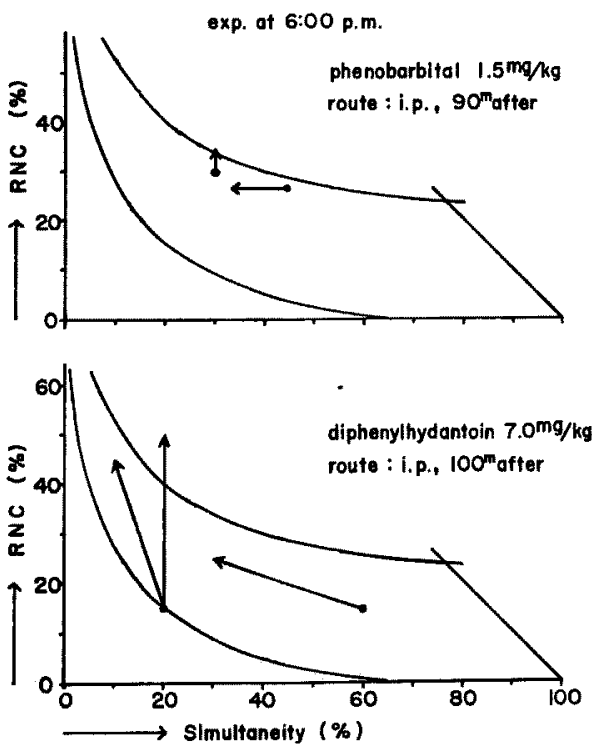

Fig. 4.
Reiationship between Simultoneity and RNC in 2El-mice
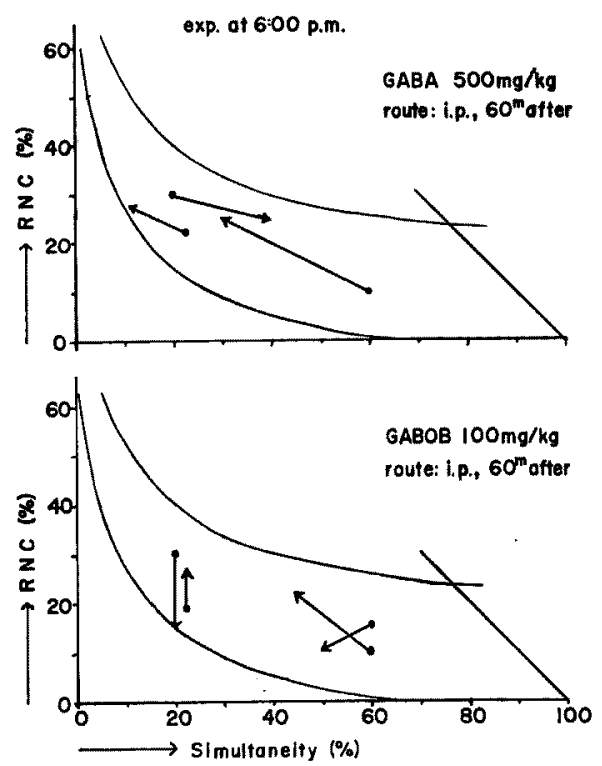

Fig. 5. 
神経の興畜之抑制を regulate する作用の一端を示すのではないかと推測した GABA について見ると，500 mg/ $\mathrm{kg}$ 投与 60m 後の成績は Fig. 5 亿示すように夕刻ではその移動先はまばらであり，はっきりした影翌は証めら れなかった。

GABOB $100 \mathrm{mg} / \mathrm{kg}$ 60m 後では朝の左上移動に対し夕䘞ではほとんど影響は認められなくなった。

$1971.6 .26 \sim 7.24$

Rolationship between Simultaneity a RNC in 2El-mice ofter administration of P-GABA or IA
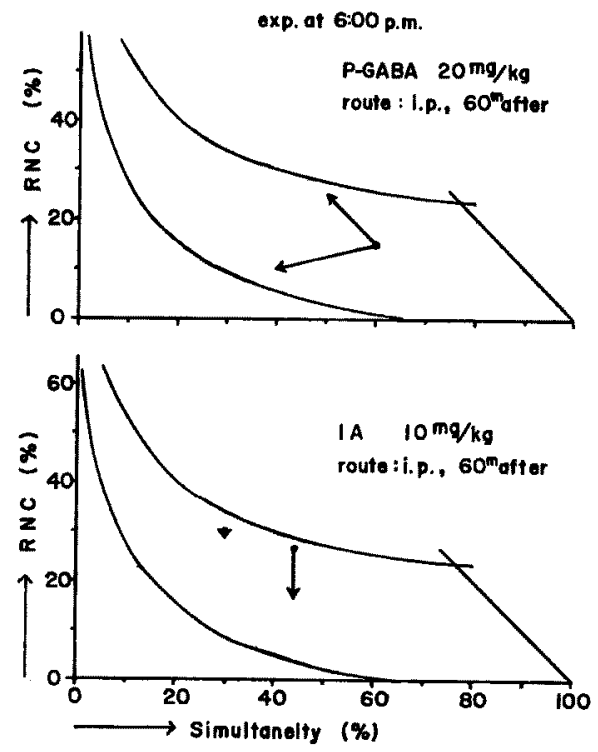

Fig. 6.

$1971.7 .5 \sim 7.28$

\section{Relationship between Difference of TSC and Simultaneliy} offer administration of anticonvulsants

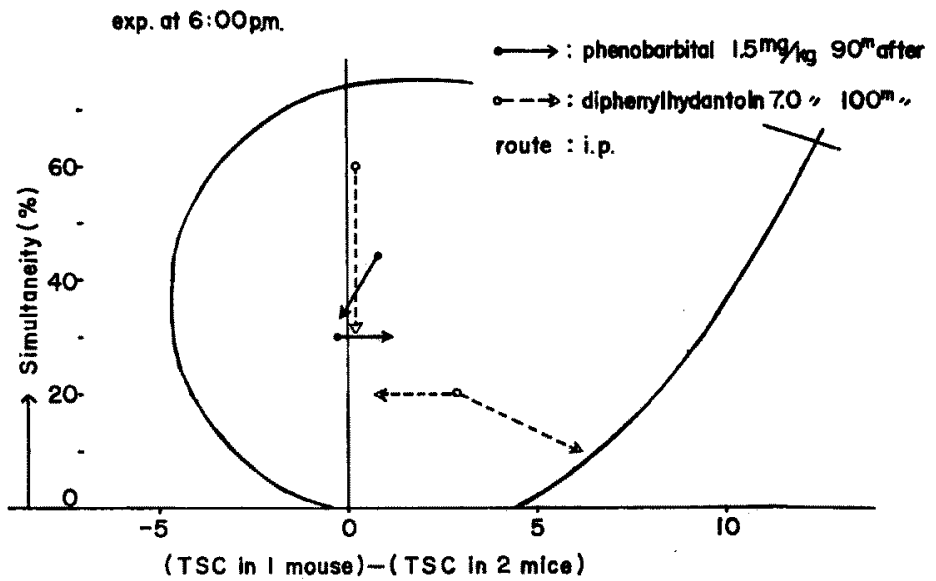

Fig. 7. 
Fig. 6 上図に示す P-GABA $20 \mathrm{mg} / \mathrm{kg}, 60 \mathrm{~m}$ 後の成績の場合も同粎, 朝は左上移動であったのに対して夕

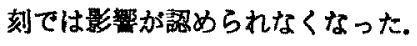

下因には IA $10 \mathrm{mg} / \mathrm{kg}$ 投与 60m 後の成續を示したが，この場合は朝夕共に影響は見られなかった。

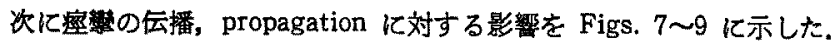

てれらの图では横軸は 1 匹単独振とう時のTSC 汃ら 2 匹同時振とう時の TSC を差引いた值を示し, 右側 方向程 propagation の大きいととを意味するが，Fig. 7 の phenobarbital または diphenylhydantoin では いずれる横軸方向の移動は大きくなく，また方向不定で propagation におよばす影響は見られなかった。

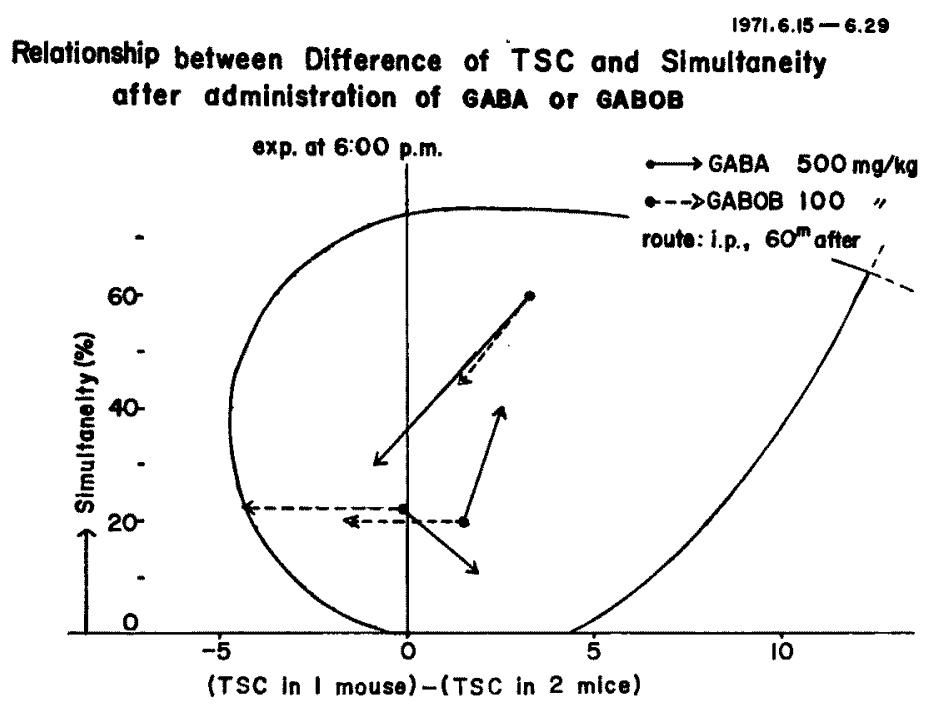

Fig. 8.

$19716.26 \sim 7.24$

Relationship between Difference of TSC and Simultaneity after administration of P-GABA or IA

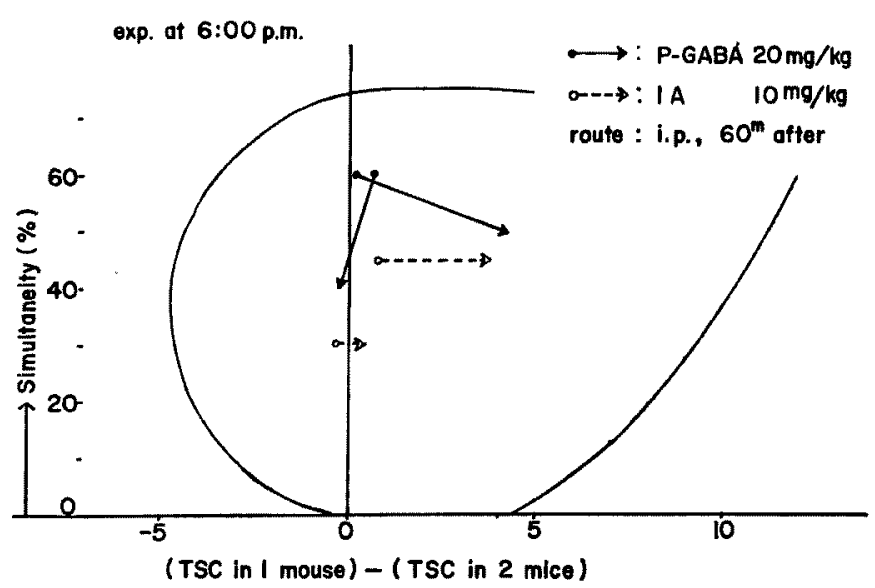

Fig. 9. 
Fig. 8 には GABA または GABOB 投与の場合を示している. GABA または GABOB は, 朝では Table 1 亿示すどとく左下向の移動を示し propagation を抑制する方向に作用した加，多刻では Fig. 8 に示すとと く, 実線で示した GABA ではその移動方向は不定であり，はっきりした作用は認められず，また破線で示した GABOB では左向きに移動し，朝と同様 propagation を抑制した.

Fig. 9 には P-GABA および IA の成績を示したが, これらの場合も影踖は認められなかった。

\section{総括ならびに考察}

われわれの周辺には種々のリズムのあることはよく知られ、人間の「てんかん」”に関してもちの発作時期

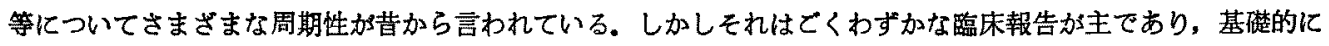
はほとんど究明されていない.

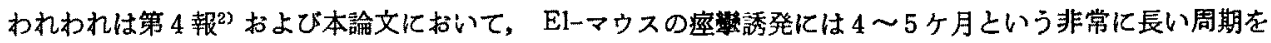
あつリズムの存在することを明らかにしたが，乙れは年令, 性を異にする多くのマウスにおいて平均的に見られ たものであるから，てのリズムはマウス個体䎲内在するすののみに起因するのてはなく，外部加らの大なる影響 を受けていると思われる.

生命現象において見られる多くのリズムの中には環境とは無関係と思われるリズムを示するのもあるが，多 玑少なかれ何らかの影響を受けていると思われる. 地球の自転, 公転という避けるととのできないリズム, あ るいは他の惑星からの測り知れない影響も否定することはできない。

本論文 Fig. 2 に El-マウス痤镍誘発の日内リズムを示したが，ての円形のグラフを見ると10時と22時をつ

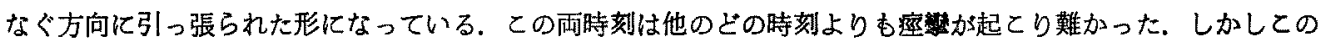

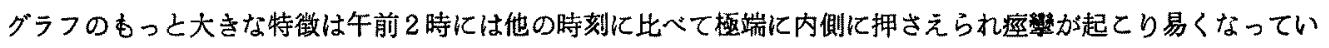
るということである. 今回のような測定方法ではすしリズムのないもの, あるいははっきりしないものならば, このグラフは六角形になってあよいであろう．とてろが 2 時の成績は一つの角をなさず, 前後の時刻の成績をつ なぐ線上にあり五角形に近くなっているということである。すすなお 2 時には外界から強く押されている印象を 受ける.

これだけならば，マウスの忣収，代謝，排泄あるいは活動性などからこの日内リズムに endogenous な原因 あ考えられようが，先の長期りズムの存在とも考え合わせると，やはり exogenous な動機によるリズム形成加 あるのかもわからない。

リズム9 形成には外因説と内因説があるが，てのようにリズム形成の外因説加ら想像を迋しくして考えてみ

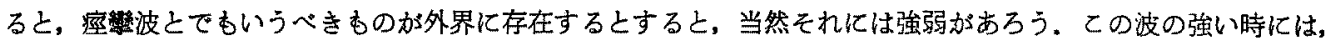

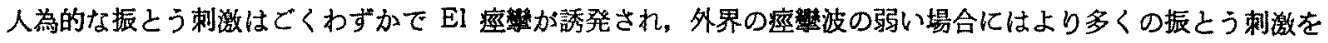
必要とするようである. 広く「痤禁」といわれているものの発現はてのような波にのっていると考元られないて ともない. その他興味あるととに，われわれの以前の実験で，TSC の小さい時期には Sim は少なく，TSC の

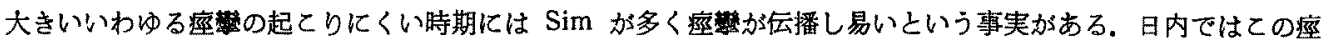
波は 2 時に最も強く 10 時と22時には弱いと考えられる。このような日内での強弱をくり返しながら大きく 4 〜 5ケ月周期で動いていると考えられる.地球が自転しながら公転しているように.

次に好酸球数変動のリズムであるが，好酸球数の增減には種々の原因がある．El一マウスにおける好酸球数

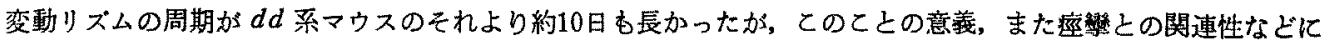
ついてはまだ何もわかっていない. El-，dd-両マウスに枋ける好酸球数の日内リズムについては目下検討中であ る.

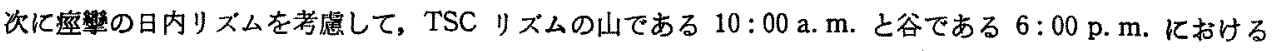
薬物の作用を，El一マウスの症栕発症における相互関係を指標として比較してみたわりであるが，今回行なった

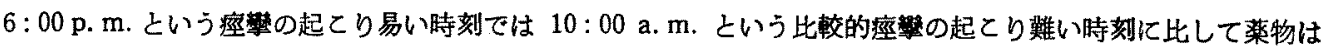
作用し難いという結果を得た。との理由についてもすへで説明は不可能である。 
このような事実から薬物の効果発現にはより適した特刻のあるととが簯われる.同じことが薬物の毒性につ いても言えるであるう，われわれは薬物のマウスに対する急性毒性は一日内の投与時刻が異なるにつれ大きく变 動するととを見出している102.

このような結果加ら薬物の投与については生体のリズム性を考虑䎲入れて適当な時刻敒与すれば，より少 量でより勃果的にその作用発現を期待できるものと思われる.

結 論

1. E1-マウス病㱷誘発の多月周期性リズムは，限られた 3 日間に出生した特定のグループで得られるリズ ムと，年令性別に関係ないマウス総群において平均的に見られるむのと概ね同じであった。

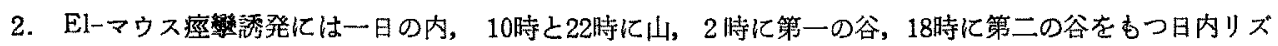
厶加存在した。

3. 血中好酸球数の変動リズムの周期は $d d$ 系マウスでは平均37日, El一マゥスでは平均47日であった.

4. El-マウス症攀発症の相互関係に対して，6:00 p. m. では薬物の影響は認め難かった.

\title{
劫 考 献
}

1）中川秀三：「てんかん一その臨床之治療法一」, 金原出版 (1963).

2）喜多富太郎，秦多恵子，村上哲男：日楽理誌，66，359 (1970).

3）秦多恵子, 村上哲男, 喜多富太郎：日薬理誌，66，435（1970）.

4) 喜多富太郎, 秦多恵子, 村上哲男：日薬理誌，66，449(1970).

5）秦多恵子，村上哲男，尾陰多津子，喜多富太郎：日薬理誌，66，669（1970）.

6）秦多恵子, 喜多富太郎：蒋誌，91，1141 (1971).

7) Kaine, H.D., Selber, H.S. \& Corn, J.W.: J. Lab. Clin. Med., 45, 247 (1955).

8) Kleitsman, N.: Physiol. Revs., 29, 1 (1949).

9) Sollberger, A.: "Biological rhythm research", Elsevier, Amsterdam, London \& New York (1965).

10）秦多恵子, 尾陰多律子, 三宅義雅，喜多富太郎：薬誌投稿中.

\begin{abstract}
KITA Tomitaro, HATA Taeko and OKAGE Tazuko. Department of Pharmacology, Faculty of Pharmacy, Kinki University, Osaka. The introduction of mass psychology to animals in pharmacology-9, Circadian rhythm and mutual relation of El-mice-convulsion at $6: 00$ p. m. to anticonvulsants. Folia pharmacol. japon. 69, 153 161 (1973).

It was reported in our 4 th paper that there was a biorhythm with one cycle of $4 \sim 5$ months in inducing El-mice-convulsion.

The biorhythm in El-mice born for 3 consecutive days was quite similar to the rhythm in the group without age-limitation.

Additionally, El-mice-convulsions had a circadian rhythm with 2 peaks in TSC (threshold of shaking-number for convulsions) at $10 \mathrm{a} . \mathrm{m}$. and $10 \mathrm{p} . \mathrm{m}$., with one of the lowest TSC peak at 2 a. m. and the 2 nd lowest level of TSC peak at 6 p. m.

At 6 p.m., influence of central-acting drugs as related to El-mice in convulsions was hardly observed, though it was observed at $10 \mathrm{a} . \mathrm{m}$.

There was a biorhythmic change in numbers of eosinophile of mice, and the cycle was $35 \sim 42$ days in $d d$-mice and $42 \sim 49$ days in El-mice.
\end{abstract}

